\title{
Łukasz Maszewski
}

Uniwersytet Mikołaja Kopernika, Toruń

maszewski@umk.pl

\section{Drogowe spółki \\ specjalnego przeznaczenia \\ jako podmioty realizujące inwestycje \\ w zakresie dróg publicznych \\ - szanse i zagrożenia (część I)*}

DOI: http://dx.doi.org/10.12775/SIT.2016.006

\section{Wprowadzenie}

Warunki tworzenia oraz zasady działalności drogowych spółek specjalnego przeznaczenia (w skrócie dssp) określa ustawa $\mathrm{z}$ dnia 12 stycznia 2007 r. o drogowych spółkach specjalnego przeznaczenia $^{1}$ (dalej jako udssp). Podmioty te może tworzyć minister właściwy do spraw transportu, działając w imieniu Skarbu Państwa, w celu przygotowania lub realizacji przedsięwzięć drogowych ustalonych spośród zadań planowanych do wykonania przez Generalnego Dyrektora Dróg Krajowych i Autostrad (art. 2 ust. 1 i 2 udssp). Do zakresu tych przedsięwzięć zalicza się m.in. budowę,

* Druk publikacji został sfinansowany przez Uniwersytet Mikołaja Kopernika w Toruniu w ramach grantu nr 2665-P. Część II artykułu została opublikowana w t. 19 (w druku).

1 Tekst jednolity: Dz.U. z 2015 r., poz. 1502. 
przebudowę, remont, utrzymanie, ochronę i zarządzanie drogami krajowymi (art. 4 ust. 2 pkt 1 i 2 udssp).

Z działalnością dssp łączono i nadal łączy się ogromne oczekiwania związane $z$ przyspieszeniem wykonania zapóźnionego programu budowy autostrad i dróg ekspresowych. Jednakże idea ta budzi tyle samo nadziei, ile obaw ${ }^{2}$. Ponieważ dotychczas nie powołano żadnej spółki tego typu, brakuje doświadczeń praktycznych związanych $\mathrm{z}$ ich działalnością ${ }^{3}$. Jak dotąd ustawodawca stworzył ustawą o dssp tylko pewien model realizacji inwestycji drogowych. Stosowanie tej ustawy, czyli wdrożenie omawianego schematu w życie, może polegać m.in. na utworzeniu spółki, obsadzeniu jej organów, określeniu zakresu jej działalności, zorganizowaniu struktury, wyposażeniu w majątek, zatrudnieniu kadry pracowników i powierzeniu zadań do wykonania. Powołanych może zostać wiele spółek, którym powierzane będą odmienne zadania, a więc poszczególne elementy modelu mogą być różnie urzeczywistniane.

Celem referatu jest określenie szans i zagrożeń dla efektywnej realizacji przedsięwzięć drogowych za pośrednictwem drogowych ssp. Chodzi przede wszystkim o szanse i zagrożenia, które są związane $z$ urzeczywistnianiem założeń ustawowego modelu dssp. Innymi słowy, chodzi o wskazanie, czy i w jaki sposób wdrożenie

2 Zob. J. Krzak, Opinia nt. rzadowego projektu ustawy o drogowych spółkach specjalnego przeznaczenia (druk nr 856) $w$ zakresie pytań sformułowanych przez Podkomisję nadzwyczajna, s. 2, http://orka.sejm.gov.pl/rexdomk5.nsf/Opwsdr?OpenForm\&856 (dostęp: 23.05.2016 r.).

3 Dopiero w 2015 r. w uchwale Rady Ministrów Nr 156/2015 z dnia 8 września 2015 r. w sprawie ustanowienia programu wieloletniego pod nazwą „Program budowy dróg krajowych na lata 2014-2023 (z perspektywą do 2025 r.)” przyjęto, że program ów będzie wykonywany także $z$ udziałem dssp. Uchwała ta określa listę zadań inwestycyjnych, które będą realizowane w formule drogowej spółki specjalnego przeznaczenia. Wskazano tam trzy takie zadania w zakresie autostrad: A1 na odcinku koniec obwodnicy Częstochowy-Tuszyn; A2 na odcinku Warszawa-Siedlce (odcinek Mińsk Mazowiecki-Siedlce); A18 na odcinku Olszyna-Golnice (przebudowa jezdni południowej), o łącznej długości 187,5 km, przy czym zakłada się pierwszeństwo inwestycji polegającej na budowie autostrady Al na odcinku Tuszyn-Częstochowa. Wskazano tam również, iż środki finansowe będą pozyskane przez dssp z rynku kapitałowego. Zob. http://mib.gov.pl/2-program_budowy_ drog_krajowych.htm\# (dostęp: 23.05.2016 r.). 
bądź sposób wdrożenia poszczególnych założeń koncepcji drogowych spółek może wpływać na efektywność wykonywania przedsięwzięć drogowych w omawianej formule. Na potrzeby referatu efektywność rozumiana będzie jako „Zdolność do takiego wykorzystania posiadanych zasobów, aby w sposób najbardziej skuteczny i najmniej marnotrawny osiągnąć dany cel"4.

$\mathrm{Na}$ wstępie należy zaznaczyć, że w niniejszym opracowaniu przyjęto założenie, iż to, czy realizacja przedsięwzięć drogowych przez dssp będzie bardziej efektywna niż wykonanie przedmiotowych inwestycji w innych trybach (np. jako zamówienie publiczne czy partnerstwo publiczno-prywatne, w skrócie ppp), zależy w dużej mierze od uwarunkowań konkretnego przedsięwzięcia. Należy w tym miejscu odwołać się do literatury dotyczącej ppp, w której przed podjęciem decyzji przez podmiot publiczny o realizacji danej inwestycji w formule ppp zaleca się przeprowadzenie szeregu analiz ${ }^{5}$. Analizy te mają umożliwić porównanie kilku różnych wariantów wykonania danego projektu i udzielenie odpowiedzi na pytanie, czy realizacja danego zadania publicznego w formule ppp jest bardziej korzystna niż jego wykonanie w innym modelu ${ }^{6}$. Wydaje się, że podobne analizy powinny być przeprowadzane przed podjęciem decyzji o wyborze trybu realizacji konkretnych inwestycji drogowych, gdzie wykonanie przedsięwzięcia przez dssp powinno być uwzględniane tylko jako jeden $z$ potencjalnych wariantów. Nie należy bowiem formuły drogowych spółek traktować jako zawsze optymalnej. Również $\mathrm{w}$ treści uzasadnienia do projektu udssp podkreślano, że omawiane podmioty mają tylko uzupełnić

4 M. Szudy, Efektywność ekonomiczna w ujęciu dynamicznym a sprawność systemu gospodarczego, „Studia Ekonomiczne” 2013, nr 176, s. 23. Na temat pojęcia efektywności w naukach ekonomicznych zob. też G. Kozuń-Cieślak, Efektywność rozważania nad istotą i typologia, „Kwartalnik Kolegium Ekonomiczno-Społecznego Studia i Prace" 2013, nr 4, s. 13-42.

5 Zob. T. Skoczyński, Ustawa o partnerstwie publiczno-prywatnym. Komentarz, Warszawa 2011, s. 66-68; Partnerstwo publiczno-prywatne. Poradnik, red. B. Korbus, Warszawa 2010, s. 77 i n.

6 Zob. E.R. Yescombe, Partnerstwo publiczno-prywatne. Zasady wdrażania ifinansowania, przeł. M. Płonka, Kraków 2008, s. 98 i n.; Ustawa o partnerstwie publiczno-prywatnym. Komentarz, red. M. Bejm, Warszawa 2014, s. 25-26. 
dotychczasowy system wykonywania inwestycji drogowych ${ }^{7}$. A zatem pozostałe elementy tego systemu wciąż mogą i powinny być stosowane.

Należy również podkreślić, że najpełniejsza i najbardziej rzetelna ocena efektywności działalności tytułowych spółek, a zatem kluczowa będzie ocena ex post, czyli dokonana dopiero po zrealizowaniu przez omawiane podmioty pierwszych inwestycji drogowych. Dopiero wtedy będzie można uwzględnić w przedmiotowej ocenie takie kwestie jak: wysokość poniesionych nakładów na wykonanie przedsięwzięcia, czas jego realizacji, to, czy dokonano $\mathrm{w}$ terminie zamknięcia finansowego, jakość oddawanych do użytku dróg czy jakość zarządzania danym odcinkiem drogi. Jednakże projekty drogowe mogą być zarządzane przez poszczególne spółki na różne sposoby, a przez to efektywność tych podmiotów może być odmienna. Może to utrudnić czy wręcz uniemożliwić dokonanie ogólnej oceny dssp, jako modelu realizacji inwestycji drogowych.

\section{Geneza poszukiwania nowego trybu realizacji przedsięwzięć drogowych}

Aby zrozumieć istotę modelu drogowych spółek specjalnego przeznaczenia, w pierwszej kolejności należy zwrócić uwagę na przyczyny wprowadzenia do polskiego porządku prawnego podstaw prawnych do powoływania tej nowej kategorii podmiotów, którym można powierzyć realizację przedsięwzięć drogowych. Jak wynika $z$ uzasadnienia do projektu udssp, podstawowym celem ustawodawcy było uzyskanie zwiększenia zdolności administracji publicznej w zakresie budowy dróg krajowych. Jednocześnie celem było stworzenie modelu efektywnego wykonywania przedmiotowych inwestycji ${ }^{8}$. Miało to umożliwić: po pierwsze, wykonanie rozszerzonego programu budowy dróg krajowych, który jest od

\footnotetext{
7 Zob. Uzasadnienie. Rządowy projekt ustawy o drogowych spótkach specjalnego przeznaczenia. Druk nr 856 z dnia 7.12.2006 r., s. 2, http://orka.sejm.gov.pl/ Druki5ka.nsf/wgdruku/856 (dostęp: 23.05.2016 r.).

8 Ibidem, s. 4.
} 
dziesięcioleci zapóźniony w realizacji ${ }^{9}$; po drugie, wykonanie obowiązków RP dotyczących jej sieci drogowej wynikających z członkostwa Polski w Unii Europejskiej ${ }^{10}$; po trzecie, wykorzystanie środków finansowych, które są przewidziane w ramach funduszy z Unii Europejskiej, dostępnych tylko czasowo m.in. na wykonywanie przedsięwzięć drogowych; po czwarte, tańszą realizację inwestycji drogowych niż w ramach dotychczas stosowanych trybów ich wykonywania ${ }^{11}$. W dalszej kolejności skutkiem realizacji zwiększonego programu budowy dróg krajowych miało być usprawnienie transportu drogowego, poprawa bezpieczeństwa i komfortu ruchu drogowego, a tym samym stworzenie nowych warunków dla działalności potencjalnych inwestorów, co miało poprawić sytuację poszczególnych regionów ${ }^{12}$.

W uzasadnieniu do projektu udssp za główną przyczynę braku możliwości realizacji wymienionych celów w trybach dotychczas

9 W literaturze podkreśla się, że żaden program budowy dróg krajowych, w szczególności autostrad i dróg ekspresowych, nigdy nie był w pełni realizowany. Wskazuje się, że polska administracja drogowa od dekad nie umiała poradzić sobie z zadaniem polegającym na realizacji programu budowy dróg publicznych o najwyższym standardzie. Plany te powstawały już od lat 30. XX w., zob. J. Kaliński, Autostrady $w$ Polsce, czyli drogi przez mękę, Łódź 2011, s. 6, 85. Zdaniem Najwyższej Izby Kontroli „nieskuteczność działania wskazuje wręcz na niemoc organów państwa w rozwiązaniu tego zagadnienia”, zob. Informacja o wynikach kontroli budowy autostrad $w$ Polsce, Najwyższa Izba Kontroli, Departament Komunikacji i Systemów Transportowych, Warszawa 2003, s. 12. Również w uzasadnieniu do projektu udssp podkreślano, że $z$ doświadczeń w omawianym zakresie wynika, iż dotychczas istniejące systemy nie były i nie będą w stanie zrealizować rządowych programów wybudowania w krótkim czasie sieci autostrad i dróg ekspresowych, zob. Ocena skutków regulacji. Rządowy projekt ustawy o drogowych spółkach specjalnego przeznaczenia. Druk nr 856 z dnia 7.12.2006 r., s. 8, http://orka.sejm.gov. pl/Druki5ka.nsf/wgdruku/856 (dostęp: 23.05.2016 r.).

10 Chodzi o obowiązki w zakresie: dostosowania nawierzchni dróg publicznych do obciążeń 11,5 t na oś oraz budowy i utrzymywania odcinków dróg publicznych zaliczanych do Transeuropejskiej Sieci Transportowej (TEN-T). Zob. Ł. Maszewski, Skutki prawne właczenia drogi publicznej do transeuropejskiej sieci transportowej. Zarys problematyki, w: Europeizacja publicznego prawa gospodarczego, red. H. Gronkiewicz-Waltz, K. Jaroszyński, Warszawa 2011, s. 379-390.

11 Projektodawcy zakładali, że dssp będą efektywnie realizowały inwestycje drogowe przy koszcie budowy i eksploatacji dróg na poziomie kosztów uzyskiwanych w systemie tradycyjnym, tj. przez administrację drogową. Zob. Ocena, s. 4.

12 Ibidem, s. 6-7. 
stosowanych wskazano niezdolność Generalnej Dyrekcji DKiA do efektywnego wykonania całego zakresu przypisanych jej zadań. Uznano, że możliwości techniczne, organizacyjne i finansowe GDDKiA w zakresie prowadzenia dużych inwestycji wyczerpały się. Dowodem na to miało być niewykorzystywanie przez GDDKiA corocznych środków finansowych przyznawanych jej na realizację przedsięwzięć drogowych ${ }^{13}$.

Wydaje się jednak, iż źródła przyczyn poszukiwania przez ustawodawcę nowego narzędzia wykonywania zadań publicznych w zakresie budowy i utrzymania dróg publicznych należy upatrywać również wśród dotychczasowych doświadczeń administracji publicznej w realizacji inwestycji drogowych we współpracy z przedsiębiorcami. Współdziałanie to przybierało postać zamówień publicznych, koncesji na budowę i eksploatację autostrad płatnych czy ppp. Można postawić tezę, że gdyby dotychczas znane tryby wykonywania przedsięwzięć drogowych dawały satysfakcjonujące stronę publiczną rezultaty, nie poszukiwano by nowych form realizacji przedmiotowych zadań publicznych.

Najbardziej powszechną postacią zlecania wykonywania zadań administracji drogowej są umowy cywilnoprawne, zawierane w trybach określonych ustawą Prawo zamówień publicznych (w skrócie pzp) ${ }^{14}$. Zamówienia publiczne stanowią znacznie prostszą formę realizacji zadań publicznych niż koncesje na roboty budowlane lub usługi bądź ppp. Współpraca w ramach zamówień publicznych opiera się bowiem na odpłatnej i pisemnej umowie, która przewiduje wynagrodzenie dla wykonawcy nieobarczone ryzykiem jego uzyskania ${ }^{15}$. Ryzyko ekonomiczne przedsięwzięcia ponosi bowiem zamawiający jego wykonanie ${ }^{16}$. Istotą zamówień publicznych jest zatem nabywanie przez zamawiającego usług, dostaw lub robót

13 Zob. Uzasadnienie, s. 2-3.

14 Ustawa z dnia 29 stycznia 2004 r. (tekst jednolity: Dz.U. z 2015 r., poz. 2164 ze zm.).

15 Zob. art. 2 pkt 13 pzp; A. Sołtysińska, H. Talago-Sławoj, Europejskie prawo zamówień publicznych. Komentarz, Warszawa 2016, s. 130; Nowe podejście do zamówień publicznych. Podręcznik, red. H. Niedziela, Warszawa 2011, s. 47.

16 Zob. wyrok Trybunału Sprawiedliwości UE z dnia 10 września 2009 r. w sprawie C-206/08 Wasser- und Abwasserzweckverband Gotha und Landkreisgemein- 
budowlanych w zamian za ustalone wynagrodzenie. Umowy tego typu znane są na całym świecie ${ }^{17}$. Głównym problemem związanym $z$ wykorzystywaniem tej formy realizacji zadań publicznych jest brak środków publicznych w wysokości wystarczającej na wykonanie wszystkich zadań publicznych w tym trybie. Można zatem zaryzykować twierdzenie, że gdyby zasoby wspomnianych środków budżetowych na to pozwalały, można by w formie zamówień publicznych skutecznie i efektywnie realizować wszystkie zadania publiczne.

W Polsce mamy także stosunkowo bogaty zakres doświadczeń, jeśli chodzi o współpracę przedsiębiorców $z$ administracją drogową określaną jako ppp. Nie chodzi tu jednak o współdziałanie regulowane umowami o ppp zawieranymi na podstawie ustaw o partnerstwie publiczno-prywatnym z $2005^{18}$ czy z 2008 r. ${ }^{19}$, ale nawiązywane na podstawie ustawy o autostradach płatnych i Krajowym Funduszu Drogowym ${ }^{20}$. Początkowo ustawa ta nie przewidywała aż tak złożonej współpracy wymienionych podmiotów, żeby uznać ją za ppp. Pierwotnie ustawodawca zakładał bowiem realizację przedsięwzięć w zakresie budowy i eksploatacji autostrad płatnych $\mathrm{w}$ modelu koncesyjnym, $\mathrm{z}$ ograniczonym ustawowo udziałem strony reprezentującej Skarb Państwa ${ }^{21}$. Koncesjonariusze wymuszali jednak stopniowo coraz większe zmiany w ustawodawstwie oraz w zawartych przez siebie umowach koncesyjnych, doprowadzając w konsekwencji do faktycznej zmiany modelu współpracy

den (WAZV Gotha) przeciwko Eurawasser Aufbereitungs- und Entsorgungsgesellschaft mbH (Dz.U. UE C 267 z 7.11.2009, s. 20).

17 Zob. The tools of government. A guide to the new governance, red. L.M. Salamon, Oxford 2002, s. 282-283.

18 Ustawa z dnia 28 lipca 2005 r. (Dz.U. z 2005 r. Nr 169, poz. 1420 ze zm.).

19 Ustawa z dnia 19 grudnia 2008 r. (tekst jednolity: Dz.U. z 2015 r., poz. 696 ze zm.).

20 Ustawa z dnia 27 października 1994 r. (tekst jednolity: Dz.U. z 2015 r., poz. 641 ze zm.).

${ }^{21}$ Zob. H. Jędrzejewski et al., Ustawa o autostradach płatnych. Komentarz, przepisy wykonawcze, Warszawa-Zielona Góra 1996, s. 9-10, 38, 71; T. Korczyński et al., Koncesja na roboty budowlane lub usługi a inne formy realizacji inwestycji publiczno-prywatnych, Warszawa 2010, s. 57-58. 
z koncesyjnego na $\mathrm{ppp}^{22}$. W wyniku dokonania tych zmian udział Skarbu Państwa w wykonywaniu inwestycji autostradowych stał się znacznie większy niż początkowo zakładano. Strona publiczna przejęła bowiem wiele ryzyk, które $z$ założenia mieli przejąć przedsiębiorcy (takie jak chociażby ryzyko popytu, czyli ryzyko natężenia ruchu) ${ }^{23}$. Uznano jednak, iż bez znacznego wsparcia ze strony publicznej wiele przedsięwzięć nie mogłoby zostać w ogóle zrealizowanych, a to $z$ uwagi na ogromną kapitałochłonność inwestycji $z$ jednej strony, a niepewne co do wysokości wpływy $z$ tytułu prawa do eksploatacji przedmiotu przedsięwzięcia $z$ drugiej strony ${ }^{24}$. Na zasadność tej tezy mogą wskazywać doświadczenia niektórych koncesjonariuszy w przedmiotowym zakresie. Wystarczy wskazać, że wymienione trudności uniemożliwiły w kilku przypadkach przedsiębiorcom dokonanie tzw. zamknięć finansowych i w konsekwencji stwierdzono wygaśnięcie udzielonych im koncesji ${ }^{25}$.

Na podstawie analizy danych statystycznych wyniki omówionej współpracy można ocenić jako sukces. Jak zwraca uwagę Beata Zagożdżon, gdyby uwzględnić wartość inwestycji autostradowych realizowanych w formule ppp w stosunku do $\mathrm{PKB}$, ulokowałoby to Polskę wśród krajów UE, które dominują w implementacji ppp

22 Zob. Informacja o wynikach kontroli zabezpieczenia interesów Skarbu Państwa $w$ umowach koncesyjnych na budowę i eksploatację autostrad A2 i A4, Najwyższa Izba Kontroli, Departament Komunikacji i Systemów Transportowych, Warszawa 2006, s. 12 .

23 Np. na podstawie umowy koncesyjnej z Gdańsk Transport Company S.A. dotyczącej budowy i eksploatacji autostrady Al Skarb Państwa zobowiązany jest nie tylko do wypłacania spółce tzw. opłaty za dostępność, ale i do wypłat w ramach tzw. gwarantowanego przychodu z opłat za przejazd autostradą. Gwarantowany przychód Krajowy Fundusz Drogowy wypłaca spółce, jeśli kwota przychodu z pobranych opłat za przejazd jest niższa od przychodu z tych opłat zagwarantowanego w umowie koncesyjnej. Zob. B. Zagożdżon, Dylematy finansowania infrastruktury transportowej $w$ formule PPP, „Logistyka” 2012, nr 2, s. 317. Zob. też Informacja o wynikach kontroli wykonywania zadań przez administrację publiczna $w$ zakresie budowy autostrady A-1 pótnoc-południe, Najwyższa Izba Kontroli, Departament Komunikacji i Systemów Transportowych, Warszawa 2006, s. 10-11; Informacja o wynikach kontroli zabezpieczenia, s. 23.

24 Zob. Informacja o wynikach kontroli wykonywania, s. 34-35.

25 Zob. B. Zagożdżon, Dylematy, s. 318. 
w przedmiotowym zakresie ${ }^{26}$. Niestety w oparciu o inne kryteria wyrażane są odmienne oceny. Wskazuje się, że zarówno system koncesyjny, jak i ppp poniosły klęskę, co miało być skutkiem przede wszystkim małego zainteresowania kapitału prywatnego budową autostrad w Polsce ${ }^{27}$. Zdaniem Najwyższej Izby Kontroli obecnie to Skarb Państwa angażuje swoje środki i ponosi ryzyko gospodarcze funkcjonowania spółek - koncesjonariuszy, odnotowując minimalny przyrost długości samych autostrad ${ }^{28}$. Podnoszony był także zarzut przyznania koncesjonariuszom zbyt dużego zakresu autonomii w zakresie zarządzania autostradami, co znalazło w literaturze wyraz chociażby w nazwaniu części odcinków autostrad „eksterytorialnymi” ${ }^{29}$. Dodatkowo realizację inwestycji finansowaną ze środków prywatnych uznaje się za droższą niż finansowaną ze środków publicznych ${ }^{30}$.

Osiągnięcie wskazanych $\mathrm{w}$ uzasadnieniu do projektu udssp celów, także poprzez eliminację wad dotychczas stosowanych modeli wykonywania przedsięwzięć drogowych, ma stać się możliwe dzięki powoływaniu drogowych spółek i powierzaniu im realizacji zadań w zakresie budowy i utrzymania dróg krajowych. W uzasadnieniu do projektu udssp podkreślano, że dssp mają stanowić nowy instrument organizacyjno-prawny, tzw. trzecią drogę, jeśli chodzi o realizację dużych przedsięwzięć infrastrukturalnych. Istota przedmiotowego modelu ma polegać na powierzaniu wykonania zadań podmiotowi prawa prywatnego zależnemu od organu administracji drogowej. Drogowe spółki mają stanowić formułę elastyczną zarówno jeśli chodzi o możliwy do powierzenia im zakres zadań, jak i o finansowanie przekazanych im do realizacji inwestycji. Mają one bowiem mieć możliwość korzystania ze środków publicznych oraz zaciągania kredytów, których spłatę poręczy Skarb Państwa. $\mathrm{Z}$ założenia nie chodzi tu zatem o zastąpienie dotychczasowych

\footnotetext{
26 Zob. idem, Infrastruktura logistyczna - możliwości finansowania przez kapitał prywatny, „Logistyka” 2014, nr 3, s. 6837.

27 Zob. J. Kaliński, op.cit., s. 85.

28 Zob. Informacja o wynikach kontroli zabezpieczenia, s. 12.

29 Zob. E. Kłossowski, Po co nam eksterytorialne autostrady, „Rzeczpospolita” 2011, nr 240, s. C10.

30 Zob. B. Zagożdżon, Dylematy, s. 319.
} 
elementów systemu wykonywania przedsięwzięć drogowych, ale o ich uzupełnienie, rozbudowę. Ponadto zakładanym celem dssp nie jest konkurowanie $z$ GDDKiA, ale stanowienie dla niej wsparcia. Zadania administracji drogowej i drogowych spółek mają być bowiem komplementarne ${ }^{31}$.

\section{Drogowe ssp jako podmioty prawa prywatnego}

Co do zasady administracja publiczna działa w określonych prawem, właściwych tylko dla siebie formach, głównie władczych w postaci wydawania aktów administracyjnych i stanowienia aktów normatywnych, ale także coraz częściej wykorzystuje w swych działaniach umowy publicznoprawne ${ }^{32}$. Przybiera również typowe dla siebie formy ustrojowo-organizacyjne, takie jak organ administracji publicznej czy zakład administracyjny (publiczny) ${ }^{33}$. Jednakże współcześnie administracja publiczna wykorzystuje w znacznym zakresie także formy działania niezastrzeżone wyłącznie dla organów administracji publicznej, takie jak umowy cywilnoprawne czy działania faktyczne. Co więcej, administracja publiczna powierza wykonywanie swych zadań także podmiotom działającym w formach ustrojowo-organizacyjnych prawa prywatnego, w tym również sama tworzy tego typu podmioty ${ }^{34}$. Zjawisko to nazwane zostało prywatyzacją realizacji zadań publicznych ${ }^{35}$.

31 Zob. Uzasadnienie, s. 2-5; Ocena, s. 2-7.

32 Zob. A. Panasiuk, Umowa publicznoprawna (próba definicji), „Państwo i Prawo" 2008, nr 2, s. 18-31.

33 Zob. E. Ochendowski, Prawo administracyjne. Część ogólna, Torun 2013, s. 185 i n., 241 i n.

34 Ibidem, s. 242.

35 Zob. S. Biernat, Prywatyzacja zadań publicznych. Problematyka prawna, Warszawa-Kraków, 1994, s. 26; L. Zacharko, Prywatyzacja zadań publicznych gminy. Studium administracyjnoprawne, Katowice 2000, s. 115; L. Kieres, Prywatyzacja - zagadnienia prawa publicznego, prawa prywatnego i polityki gospodarczej, w: Prawne aspekty prywatyzacji, red. J. Blicharz, Wrocław 2012, s. 85-86; T. Kocowski, Prywatyzacja zarzadzania majątkiem publicznym, prywatyzacja majątkowa, prywatyzacja zadań publicznych i prywatyzacja wykonania zadań publicznych, w: Prawne, s. 38. 
Jego przyczyn upatruje się w konieczności zapewnienia wykonania coraz szerszego i bardziej złożonego zakresu zadań publicznych, a także w potrzebie zapewnienia odpowiedniej skuteczności i efektywności działań administracji publicznej, szczególnie w dobie kryzysu gospodarczego i wynikającego stąd permanentnego niedoboru środków publicznych. Nie bez wpływu na opisane zmiany pozostaje także wzrost oczekiwań społecznych wobec jakości świadczonych usług publicznych. Wykorzystywanie przez administrację publiczną $\mathrm{w}$ coraz większym zakresie form prawa prywatnego ma zatem, $z$ założenia, stanowić swoiste remedium na bolączki trapiące administrację publiczną ${ }^{36}$.

W rozważaniach nad statusem prawnym dssp szczególnego znaczenia nabiera właśnie kwestia wykorzystywania przez administrację publiczną form organizacyjno-prawnych prawa prywatnego. Za powoływaniem tego typu podmiotów w celu realizacji zadań administracji publicznej przemawia „motyw ekonomicznego działania administracji w określonych dziedzinach, ukierunkowany na elastyczne, efektywne i odbiurokratyzowane działanie administracji w sferze gospodarczej” ${ }^{37}$. Zadania państwa są na tyle złożone, że część z nich można wykonywać lepiej w innych niż tradycyjne formach organizacyjno-prawnych. Zjawisko to znane jest od dawna. W literaturze określa się je mianem prywatyzacji organizacyjnej ${ }^{38}$. W związku z tym uprawnione jest mówienie o szansach, jakie niesie ze sobą realizacja inwestycji drogowych przez drogowe spółki, $z$ uwagi na to, że będą to podmioty zorganizowane i zarządzane na takich samych zasadach jak podmioty prywatne.

Już podczas prac nad projektem udssp wskazano, iż podmioty administracji publicznej, którym nadano prywatnoprawną formę ustrojowo-organizacyjną, pod wieloma względami mogą lepiej od-

\footnotetext{
36 Zob. S. Biernat, op.cit., s. 34; T. Kocowski, op.cit., s. 54; M. Zawicki, Nowe zarzadzanie publiczne, Warszawa 2011, s. 22-23.

37 Prawo gospodarcze. Zagadnienia administracyjnoprawne, red. H. Gronkiewicz-Waltz, M. Wierzbowski, Warszawa 2011, s. 107-108.

38 Zob. S. Biernat, op.cit., s. 69, 105; Ch. Zeiss, Privatfinanzierung staatlicher Infrastruktur. Modelle, Strukturen, nationales Haushaltsverfassungsrecht und Wettbewerbsorientierung des Gemeinschaftsrechts, Bonn 2000, s. 19; J.A. Kämmerer, Privatisierung: Typologie - Determinanten - Rechtspraxis - Folgen, Tübingen 2001, s. 41-44.
} 
najdywać się w rzeczywistości rynkowej niż organy administracji publicznej ${ }^{39}$. Podkreślano, iż „utworzone spółki będą pozbawione całej biurokratycznej otoczki, charakterystycznej dla administracji państwowej” ${ }^{40}$. Można tu zatem wykorzystać wszelkie zalety spółek prawa handlowego, w przypadku których struktura organizacyjna może być znacznie lepiej dostosowana do zadań, jakie taki podmiot ma wykonywać niż w przypadku organu administracji publicznej. W tym kontekście dodatkową zaletą omawianych podmiotów może być także mniejszy zakres zadań, jakie będą im powierzane w porównaniu z zakresem zadań GDDKiA. Nastawienie zadaniowe dssp umożliwia takie ukształtowanie ich struktur wewnętrznych, by minimalizować koszty, a maksymalizować efekty ${ }^{41}$.

Współcześnie jednak wobec prywatyzacji realizacji zadań publicznych formułuje się cały szereg zarzutów. W nauce nie neguje się już znaczenia podmiotów administracji publicznej w wykonywaniu zadań publicznych. Czynili tak zwłaszcza przedstawiciele nurtu New Public Management, którzy w prywatyzacji upatrywali jedynej słusznej drogi realizacji zadań publicznych, a w administracji publicznej dopatrywali się problemu samego w sobie ${ }^{42}$. Obecnie coraz

39 Zob. Biuletyn z posiedzenia Komisji Infrastruktury (Nr 103), $\mathrm{Nr} 1344 / \mathrm{V} \mathrm{kad}$. 5.12.2006 r., Kancelaria Sejmu, Biuro Komisji Sejmowych, s. 7, http://orka.sejm. gov.pl/Biuletyn.nsf/0/6AFDCA928C55DF27C125725300406446/\$file/0134405. pdf (dostęp: 23.05.2016 r.).

40 J. Krzak, op.cit., s. 2.

${ }^{41}$ Decentralizacja, dezagregacja dużych organizacji publicznych i koncentracja na zadaniu to założenia koncepcji New Public Management. Zob. M. Kulesza, D. Sześciło, Polityka administracyjna i zarzadzanie publiczne, Warszawa 2013, s. 64; A. Zalewski, Reformy sektora publicznego $w$ duchu nowego zarzadzania publicznego, $\mathrm{w}$ : Nowe zarzadzanie publiczne $w$ polskim samorzadzie terytorialnym, red. A. Zalewski, Warszawa 2007, s. 27; K. Marchewka-Bartkowiak, Nowe zarzadzanie publiczne, „Infos BAS” 2014, nr 18, s. 2-3, http://orka.sejm.gov.pl/WydBAS.nsf/0/24E1231535A8BDE5C1257D6A003B6AEA/\$file/Infos_178.pdf(dostęp:23.05.2016 r.). Stąd sugeruje się, aby drogowym ssp nie powierzać zarządzania drogami, ale wyłącznie przygotowywanie i realizację inwestycji. Skoro bowiem chodzi o przyspieszenie budowy dróg publicznych o najwyższym standardzie, to spółka powinna zrealizować inwestycję i oddać jej przedmiot w zarządzanie GDDKiA. Zakreślenie zbyt szerokiego zakresu zadań dssp może zatem stanowić zagrożenie dla skuteczności i efektywności jej działalności. Zob. J. Krzak, op.cit., s. 4.

42 Zob. The tools, s. 592. Również pod adresem projektu ustawy o dssp sformułowano zarzut, że jego podstawowe założenia są fałszywe. Chodziło o przyjęcie 
częściej podkreśla się wręcz, że nauka nie dość dostatecznie bada, czy rzeczywiście prywatyzacja przynosi lepsze efekty niż tradycyjne sposoby wykonywania zadań publicznych ${ }^{43}$. Przedstawiciele koncepcji governance zauważają nawet, że do rozwiązywania problemów społecznych nie wystarczają już samodzielne środki ani wiedza administracji publicznej bądź podmiotów prywatnych, stąd konieczna jest ich współpraca $\mathrm{w}$ tym zakresie ${ }^{44}$. W kontekście prywatyzacji organizacyjnej podnosi się natomiast, iż zmiana samej tylko formy organizacyjno-prawnej, wobec braku zmian w zakresie zarządzania danym podmiotem czy wobec braku konkurencji na danym rynku usług publicznych - nie przynosi spodziewanych rezultatów ${ }^{45}$.

Należy zatem przyjąć, że wykorzystywanie prywatnoprawnych form organizacyjnych do realizacji zadań publicznych zamiast form publicznoprawnych samo w sobie nie gwarantuje bardziej efektywnego wykonywania zadań publicznych. Stwarza jednak nowe możliwości, takie jak chociażby możliwość uelastycznienia struktury wewnętrznej, wdrożenia menedżerskiego sposobu zarządzania oraz profesjonalizacji kadry pracowników, a zatem pośrednio może przyczynić się do zwiększenia przedmiotowej efektywności.

\section{Sposób zarządzania oraz potencjał kadrowy dssp}

Wdrożenie menedżerskiego sposobu zarządzania drogowymi spółkami uznawane jest za szansę na zwiększenie efektywności realizowanych przez nie przedsięwzięć drogowych ${ }^{46}$. To właśnie umie-

w nim za punkt wyjścia, że administracja rządowa nie jest w stanie fachowo realizować przedmiotowych zadań, w przeciwieństwie do dssp, jako podmiotów prywatnych. Zob. Biuletyn z posiedzenia Komisji Infrastruktury (nr 73) Nr 1019/V kad. 24.08.2006 r., Kancelaria Sejmu, Biuro Komisji Sejmowych, s. 9, http://orka.sejm. gov.pl/Biuletyn.nsf/0/91F7FCB829B1AC23C12571FD00499A4D/\$file/0101905. pdf (dostęp: 24.05.2016 r.).

43 Zob. W. Hoff, Granice prywatyzacji zadań i kompetencji władz publicznych, „Krytyka Prawa” 2007, t. 7, nr 1, s. 88.

${ }_{44}$ Zob. M. Kulesza, D. Sześciło, op.cit., s. 117.

45 Zob. E.R. Yescombe, op.cit., s. 67; A. Zalewski, op.cit., s. 62.

46 Zob. Uzasadnienie, s. 3. 
jętności menedżerów decydują o sukcesie bądź porażce wykonania danego projektu. W związku z tym zagrożeniem dla ziszczenia się pokładanych w dssp nadziei będzie traktowanie stanowisk w spółkach jako synekur, które powierzane będą w oderwaniu od posiadanych przez dane osoby kompetencji. Na to niebezpieczeństwo zwracano uwagę już podczas prac nad projektem udssp ${ }^{47}$. Jak podkreślał Jacek Krzak, powstanie „przynajmniej kilkadziesiąt nowych, eksponowanych stanowisk (zarządy spółek, rady nadzorcze) wynagradzanych $z$ pieniędzy podatników - które wbrew intencjom autorów, mogą łatwo stać się atrakcyjnymi i bezpiecznymi synekurami. Atrakcyjnymi - gdyż zarządy spółek będą dysponowały dużymi środkami finansowymi, prawem organizowania przetargów czy wyboru operatorów dróg. Bezpiecznymi - gdyż ustawa przyznaje zarówno wynagrodzenie prowizyjne (finansowane $z$ pewnego źródła, jakim są pieniądze publiczne), jak i z kredytów (w pełni gwarantowanych przez Skarb Państwa)"48. Wydaje się, że wspomniane zagrożenie jest jednym $z$ najpoważniejszych dla drogowych spółek. Jeśli omawianymi podmiotami będą kierowały osoby bez odpowiedniej wiedzy i doświadczenia zawodowego - nie będzie szans na zrealizowanie podkładanych w dssp oczekiwań.

Większa efektywność dssp ma wynikać także z możliwości wykorzystywania w ich działalności wysoko kwalifikowanej kadry pracowników $^{49}$. A zatem szansą dla omawianych podmiotów będzie zatrudnienie najlepszych fachowców, co wynikałoby głównie z możliwości stosowania przez drogowe spółki wynagrodzeń w wysokościach „rynkowych” ${ }^{50}$. W literaturze podkreśla się jednak, że rynek specjalistów z sektora drogowego „nie jest z gumy”. Jak przewidywali Wojciech Hartung i Kacper Sampławski - drogowe spółki będą najprawdopodobniej zasilane pracownikami GDDKiA, co spowoduje dalsze jej osłabienie ${ }^{51}$. A zatem wskazywano, że funkcjonowa-

\footnotetext{
47 Zob. Biuletyn z posiedzenia Komisji Infrastruktury (nr 73), s. 5.

48 J. Krzak, op.cit., s. 2.

49 Zob. Uzasadnienie, s. 3.

50 Zob. Biuletyn z posiedzenia Komisji Infrastruktury (nr 73), s. 5.

51 Zob. W. Hartung, K. Sampławski, Drogowe spółki specjalnego przeznaczenia - drogi do EURO 2012 czy kolejne drogi donikąd? „Prawo Zamówień Publicznych” 2007, nr 3, s. 19.
} 
nie dssp może wtórnie pogłębić problemy organizacyjno-kadrowe GDDKiA $^{52}$, dla której miały stanowić wsparcie. Wydaje się jednak, że wagę tego ostatniego zarzutu osłabia fakt, że do podmiotów prywatnych, np. spółek, którym powierzono budowę i eksploatację autostrad płatnych, również mogą przechodzić pracownicy z GDDKiA. Można zatem postawić tezę, że powoływanie jakichkolwiek podmiotów realizujących inwestycje drogowe odrębnych od GDDKiA może ją osłabić w takim samym stopniu, jak funkcjonowanie drogowych spółek. W literaturze istnienie konkurencji pomiędzy przedsiębiorcami wykonującymi przedsięwzięcia drogowe uznaje się za niezbęd$\mathrm{n}^{53}$ i nikt nie sugeruje ograniczania działalności takich podmiotów. Ponadto nie można zakładać, że zasoby kadrowe, $z$ których mogłyby czerpać dssp, są ograniczone wyłącznie do pracowników GDDKiA czy wyłącznie do specjalistów krajowych. Należy uwzględnić możliwość zatrudniania osób $z$ sektora prywatnego, w tym także z zagranicy. Aby jednak tak się stało, spółka musi dysponować środkami finansowymi w odpowiedniej wysokości. Bez tego ta podstawowa szansa wynikająca $z$ zatrudnienia profesjonalnej kadry pracowników nie zostanie wykorzystana. Jeżeli jednak problemem będzie niedostateczna liczba specjalistów z branży drogowej na rynku, to samo powoływanie dssp tego problemu nie rozwiąże.

\section{STRESZCZENIE}

Drogowe spółki specjalnego przeznaczenia jako podmioty realizujące inwestycje w zakresie dróg publicznych - szanse i zagrożenia (część I)

Drogowe spółki specjalnego przeznaczenia (w skrócie dssp) miały stanowić nową kategorię podmiotów realizujących inwestycje drogowe w Polsce.

\footnotetext{
52 Na możliwość powstania braków kadrowych w Oddziałach GDDKiA w związku z powoływaniem dssp zwracało również uwagę Stowarzyszenie Inżynierów i Techników Komunikacji RP w piśmie z dnia 1 lipca 2013 r. przedstawionym w ramach konsultacji społecznych nad projektem ustawy o zmianie ustawy o drogowych spółkach specjalnego przeznaczenia oraz ustawy o autostradach płatnych oraz o Krajowym Funduszu Drogowym z dnia 18.06.2013 r. Zob. http://legislacja.rcl.gov.pl/ docs//2/166600/166603/166606/dokument79174.pdf (dostęp: 23.05.2016 r.).

53 Zob. W. Hartung, K. Sampławski, op.cit., s. 23.
} 
Z działalnością dssp łączono i nadal łączy się ogromne nadzieje związane z przyspieszeniem wykonania zapóźnionego programu budowy autostrad i dróg ekspresowych. Jednakże koncepcja ta budzi tyle samo nadziei, ile obaw. Ponieważ dotychczas nie powołano żadnej spółki tego typu, brakuje doświadczeń praktycznych związanych z wykonywaniem przez nie przedsięwzięć drogowych. Celem referatu jest określenie szans i zagrożeń dla efektywnej realizacji inwestycji drogowych za pośrednictwem dssp. Chodzi przede wszystkim o szanse i zagrożenia, które są związane $z$ urzeczywistnianiem założeń ustawowego modelu omawianych spółek. W części pierwszej niniejszego opracowania analizie poddane zostały zagadnienia prywatnoprawnej podmiotowości, sposobu zarządzania i potencjału kadrowego drogowych spółek specjalnego przeznaczenia.

Słowa kluczowe: drogowe spółki specjalnego przeznaczenia; inwestycje w zakresie dróg publicznych; zarządzanie drogami publicznymi

\section{SUMMARY}

Special purpose road companies as entities implementing investment in public roads - opportunities and threats (part I)

Special purpose road companies (abbreviated to SPRC) were supposed to be a new category of entities performing road investments in Poland. It was expected that the activities of such companies will contribute to accelerate the implementation of a backward program of construction of motorways and expressways in Poland. However, this concept raises as much hope as fear. No company of this type has yet been established so there is no practical experience related to their realization of road projects. The aim of this paper is to identify opportunities and threats to the effective implementation of road projects through SPRC. It is mainly about opportunities and threats which are associated with the implementation of the statutory rules of the model of these companies. In the first part of this study are analyzed the issues of the subjectivity of private law, the way of management and personnel potential of SPRC.

Keywords: special purpose road companies; investment in public roads; management of public roads 


\section{BIBLIOGRAFIA}

Biernat S., Prywatyzacja zadań publicznych. Problematyka prawna, Warszawa-Kraków 1994.

Hartung W., Sampławski K., Drogowe spółki specjalnego przeznaczenia - drogi do EURO 2012 czy kolejne drogi donikąd? „Prawo Zamówień Publicznych” 2007, nr 3.

Hoff W., Granice prywatyzacji zadań i kompetencji władz publicznych, „Krytyka Prawa” 2007, t. 7, nr 1.

Informacja o wynikach kontroli budowy autostrad $w$ Polsce, Najwyższa Izba Kontroli, Departament Komunikacji i Systemów Transportowych, Warszawa 2003.

Informacja o wynikach kontroli wykonywania zadań przez administrację publiczna $w$ zakresie budowy autostrady A-1 północ-południe, Najwyższa Izba Kontroli, Departament Komunikacji i Systemów Transportowych, Warszawa 2006.

Informacja o wynikach kontroli zabezpieczenia interesów Skarbu Państwa $w$ umowach koncesyjnych na budowe i eksploatację autostrad A2 i A4, Najwyższa Izba Kontroli, Departament Komunikacji i Systemów Transportowych, Warszawa 2006.

Jędrzejewski H. et al., Ustawa o autostradach płatnych. Komentarz, przepisy wykonawcze, Warszawa-Zielona Góra 1996.

Kaliński J., Autostrady w Polsce, czyli drogi przez mękę, Łódź 2011.

Kämmerer J.A., Privatisierung: Typologie - Determinanten - Rechtspraxis - Folgen, Tübingen 2001.

Kieres L., Prywatyzacja - zagadnienia prawa publicznego, prawa prywatnego i polityki gospodarczej, w: Prawne aspekty prywatyzacji, red. J. Blicharz, Wrocław 2012.

Kłossowski E., Po co nam eksterytorialne autostrady, „Rzeczpospolita” 2011, nr 240.

Kocowski T., Prywatyzacja zarządzania majątkiem publicznym, prywatyzacja majatkowa, prywatyzacja zadań publicznych i prywatyzacja wykonania zadań publicznych, w: Prawne aspekty prywatyzacji, red. J. Blicharz, Wrocław 2012.

Korczyński T. et al., Koncesja na roboty budowlane lub usługi a inne formy realizacji inwestycji publiczno-prywatnych, Warszawa 2010.

Kozuń-Cieślak G., Efektywność - rozważania nad istotą i typologia, „Kwartalnik Kolegium Ekonomiczno-Społecznego Studia i Prace” 2013, nr 4.

Krzak J., Opinia nt. rząowego projektu ustawy o drogowych spółkach specjalnego przeznaczenia (druk nr 856) $w$ zakresie pytań sformuło- 
wanych przez Podkomisję nadzwyczajna, http://orka.sejm.gov.pl/ rexdomk5.nsf/Opwsdr?OpenForm\&856 (dostęp: 23.05.2016 r.).

Kulesza M., Sześciło D., Polityka administracyjna i zarządzanie publiczne, Warszawa 2013.

Marchewka-Bartkowiak K., Nowe zarządzanie publiczne, "Infos BAS” 2014, $\mathrm{nr}$ 18, http://orka.sejm.gov.pl/WydBAS.nsf/0/24E1231535A8BDE5C1257D6A003B6AEA/\$file/Infos_178.pdf (dostęp: 23.05.2016 r.).

Maszewski Ł., Skutki prawne właczenia drogi publicznej do transeuropejskiej sieci transportowej. Zarys problematyki, w: Europeizacja publicznego prawa gospodarczego, red. H. Gronkiewicz-Waltz, K. Jaroszyński, Warszawa 2011.

Nowe podejście do zamówień publicznych. Podręcznik, red. H. Niedziela, Warszawa 2011.

Ocena skutków regulacji. Rządowy projekt ustawy o drogowych spótkach specjalnego przeznaczenia. Druk nr 856 z dnia 7.12.2006 r., http://orka.sejm.gov.pl/Druki5ka.nsf/wgdruku/856 (dostęp: 23.05.2016 r.).

Ochendowski E., Prawo administracyjne. Część ogólna, Torun 2013.

Panasiuk A., Umowa publicznoprawna (próba definicji), „Państwo i Prawo” 2008, nr 2.

Partnerstwo publiczno-prywatne. Poradnik, red. B. Korbus, Warszawa 2010.

Prawo gospodarcze. Zagadnienia administracyjnoprawne, red. H. Gronkiewicz-Waltz, M. Wierzbowski, Warszawa 2011.

Skoczyński T., Ustawa o partnerstwie publiczno-prywatnym. Komentarz, Warszawa 2011.

Sołtysińska A., Talago-Sławoj H., Europejskie prawo zamówień publicznych. Komentarz, Warszawa 2016.

Szudy M., Efektywność ekonomiczna w ujęciu dynamicznym a sprawność systemu gospodarczego, „Studia Ekonomiczne” 2013, nr 176.

The tools of government. A guide to the new governance, red. L.M. Salamon, Oxford 2002.

Ustawa o partnerstwie publiczno-prywatnym. Komentarz, red. M. Bejm, Warszawa 2014.

Uzasadnienie. Rządowy projekt ustawy o drogowych spółkach specjalnego przeznaczenia. Druk nr 856 z dnia 7.12.2006 r., http://orka.sejm. gov.pl/Druki5ka.nsf/wgdruku/856 (dostęp: 23.05.2016 r.).

Yescombe E.R., Partnerstwo publiczno-prywatne. Zasady wdrażania i finansowania, przeł. M. Płonka, Kraków 2008.

Zacharko L., Prywatyzacja zadań publicznych gminy. Studium administracyjnoprawne, Katowice 2000. 
Zagożdżon B., Dylematy finansowania infrastruktury transportowej $w$ formule PPP, „Logistyka” 2012, nr 2.

Zagożdżon B., Infrastruktura logistyczna - możliwości finansowania przez kapitał prywatny, „Logistyka” 2014, nr 3.

Zalewski A., Reformy sektora publicznego $w$ duchu nowego zarzadzania publicznego, w: Nowe zarzadzanie publiczne $w$ polskim samorzadzie terytorialnym, red. A. Zalewski, Warszawa 2007.

Zawicki M., Nowe zarządzanie publiczne, Warszawa 2011.

Zeiss Ch., Privatfinanzierung staatlicher Infrastruktur. Modelle, Strukturen, nationales Haushaltsverfassungsrecht und Wettbewerbsorientierung des Gemeinschaftsrechts, Bonn 2000. 
